\title{
Variance Component Analysis of Quantitative Traits in Muskmelon (Cucumis melo L.)
}

\author{
B. Praveen Kumar Reddy ${ }^{1 *}$, Hameedunnisa Begum ${ }^{2}$, N. Sunil ${ }^{3}$ and M. Thirupathi Reddy ${ }^{1}$ \\ ${ }^{1}$ Department of Horticulture, College of Horticulture, Dr. Y.S.R. Horticultural University, \\ Rajendranagar, Hyderabad-500030, Andhra Pradesh, India \\ ${ }^{2}$ Vegetable Research Station, Dr. Y.S.R. Horticultural University, Rajendranagar, Hyderabad- \\ 500030, Andhra Pradesh, India \\ ${ }^{3}$ National Bureau of Plant Genetic Resources Regional Station, Rajendranagar, Hyderabad- \\ 500030, Andhra Pradesh, India \\ *Corresponding author
}

\section{A B S T R A C T}

\begin{tabular}{l} 
Key w or d s \\
Genetic advance, \\
Genotypic \\
coefficient of \\
variation, Genotypic \\
variance, \\
Heritability, \\
Phenotypic \\
coefficient of \\
variation, \\
phenotypic \\
variance. \\
\hline Article Info \\
\hline $\begin{array}{l}\text { Accepted: } \\
\text { 26 May } 2017 \\
\text { Available Online: } \\
\text { 10 June } 2017\end{array}$ \\
\hline
\end{tabular}

A study was undertaken to understand the genetics of yield formation traits in muskmelon (Cucumis melo L.) germplasm collected from Andhra Pradesh, India that has potential for yield improvement. Thirty five genotypes were evaluated in a randomized block design with three replications during late rabi season at the Vegetable Research Station, Rajendranagar, Hyderabad, Andhra Pradesh, India. Analysis of variance revealed significant differences for almost all the characters under study except number of fruits per vine indicating presence of sufficient amount of variability in the germplasm under study offering ample scope for improving the population for these characters. The ranges of mean values revealed sufficient variation for all the traits under study. Average fruit weight, fruit cavity length and rind thickness had high magnitude of genotypic coefficient of variation. The magnitude of phenotypic coefficients of variation was higher than the corresponding genotypic coefficients of variation for all the seventeen characters under study. Selection may be effective for days to appearance of first staminate flower, fruit length, average fruit weight, fruit cavity length, fruit cavity width, rind thickness, total soluble solids and seed yield per fruit had high estimates of heritability coupled with high genetic advance as percent of mean.

\section{Introduction}

Muskmelon (Cucumis melo L.) is an economically important dicotyledonous vining vegetable in the cucurbitaceae family. While often referred to as cantaloupes, melons with the characteristic netted rind are actually muskmelons. Persia and Transcaucasus are believed to be the main centers of origin including the northwest provinces of India and Afghanistan. At present, muskmelon is cultivated under both tropical and subtropical climatic conditions throughout the world. It is a common dessert crop grown in northern and southern India. Being a hot and dry season crop and sensitive 
to cold temperatures, it is mainly grown as a summer crop in southern India. It is one of the most valued summer fruits because of its high nutritive and medicinal value, musky flavour, sweetness and aroma. It is a medium duration crop requiring a fairly long growing season from seed to marketable fruit. Its ripe fruits are used as a dessert fruit. Although current cultivars of musk melon have an advantage in plant growth and earliness characters, it gives low yield and unattractive fruit characters resulting in lower price.

Maximization of yield is one of the most important objectives of muskmelon breeding programmes. Continued yield increases in musk melon will likely depend on the availability and use of genetic variability and breeding for yield or yield-related traits. Germplasm is an indispensible material to plant breeders and germplasm collection is essential to crop improvement. Systematic study and evaluation of germplasm is imperative to understand the genetic background and the breeding value of the available germplasm and is of great importance for current and future agronomic and genetic improvement of the crop. The germplasm collections of muskmelon have not been well characterized from the point of view of its exploitation for the improvement of yield in general, and fruit quality in particular. Since musk melon is classified as a cross-pollinated crop, plant architectural and fruit character variability could be high among its population.

Yield is a complex character influenced by many components. Yield and its components are quantitative characters and are affected by environment (1). Due to the complex inheritance of yield-related traits, breeding for yield in many crop species has been difficult (2). Direct selection for yield is not effective. Efficient selection for yield in crops requires the estimation of genetic parameters for the strategic planning and allocation of limited resources. Determining the components of variability in yield and its components will also enable us to know the extent of environmental influence on yield. The genetic variance of any quantitative trait is composed of additive variance (heritable) and nonadditive variance and include dominance and epitasis (non-allelic interaction). Therefore, it becomes necessary to partition the observed phenotypic variability into its heritable and non-heritable components with suitable parameters such as phenotypic and genotypic coefficient of variation, heritability, genetic advance and genetic advance as percent of mean. It is, therefore, important in choosing an appropriate breeding programme for improving yield in any crop to know the mean value, variability, heritability of the and yield components.

Heritability provides an idea to the extent of genetic control for expression of a particular trait and the reliability of phenotype in predicting its breeding value (3). High heritability indicates less environmental influence in the observed variation (4).

It also gives an estimate of genetic advance a breeder can expect from selection applied to a population and help in deciding on what breeding method to choose (5). Genetic advance which estimates the degree of gain in a trait obtained under a given selection pressure is another important parameter that guides the breeder in choosing a selection programme (6). High heritability and high genetic advance for a given trait indicates that it is governed by additive gene action and, therefore, provides the most effective condition for selection (3).

The objectives of this study were to investigate the amount of morphological variation present in muskmelon germplasm, to estimate the genotypic and phenotypic 
components of variance in growth, earliness and yield associated traits and to predict the response to selection with a view to recommending breeding methods for the improvement of the crop.

\section{Materials and Methods}

The research was conducted at the Experimental Farm, Vegetable Research Station, Rajendranagar, Hyderabad, Andhra Pradesh, India. The study was undertaken during the late rabi season (November 2010 February 2011). The materials used in the study were 35 germplasm lines of musk melon (accession IDs starting with RNKM in Table 1). The genotypes were evaluated in a randomized block design with three replications. Seeds were initially sown in plug trays in the shadenet house nursery in the first week of November 2011. Twenty five days old container raised seedlings were transplanted in the main field in the first week of December, 2011. In each replication, each germplasm line was grown in a single row plot of $3.6 \mathrm{~m}$ length and $2 \mathrm{~m}$ width. A row-torow spacing of $2 \mathrm{~m}$ and plant-to-plant spacing of $60 \mathrm{~cm}$ was adopted. A plant population of 6 plants per plot, row and genotype was maintained. Plants were furrow irrigated, fertilized and treated to protect them from pathogens and pests by following standard practices.

All the recommended package of practices was followed to get complete expression of traits under study. The observations were recorded on five randomly selected plants from each genotype in each replication for vine length $(\mathrm{cm})$, number of primary branches per vine, fruit length $(\mathrm{cm})$, fruit diameter $(\mathrm{cm})$, average fruit weight $(\mathrm{g})$, number of fruits per vine, fruit cavity length $(\mathrm{cm})$, fruit cavity width $(\mathrm{cm})$, rind thickness $(\mathrm{mm})$, pulp thickness $(\mathrm{cm})$, total soluble solids $\left({ }^{\circ}\right.$ Brix $)$, seed yield (g/fruit), fruit yield (kg/plant) and on whole plot basis for days to appearance of first staminate flower, days to appearance of first pistillate flower, node number of first pistillate flower, days to first fruit harvest, days to last fruit harvest and total yield per plant (g). Analysis of variance was done as per the standard formulae (7). Estimates of phenotypic, genotypic and error variances were done as per the standard formulae (8). Estimates of phenotypic and genotypic coefficients of variation were calculated as per the standard formulae (9). The phenotypic coefficient of variation (PCV) and genotypic coefficient of variation (GCV) values were classified (10) as low (<10\%), moderate (10$20 \%)$ and high $(>20 \%)$. The broad sense heritability was estimated for all the characters as the ratio of genotypic variance to total or phenotypic variance (8). The heritability values were classified (11) as low $(<30 \%)$, moderate $(30-60 \%)$ and high $(>60 \%)$. The expected genetic gain or advance under selection for each character was estimated by following the standard method (11). The estimates of genetic advance and genetic advance as percent of mean were classified (11) as low $(<10 \%)$, moderate (10-20\%) and high $(>20 \%)$.

\section{Results and Discussion}

From the analysis of variance (Table 1), it is evident that highly significant differences among the genotypes were observed for almost all the characters under study except number of fruits per vine indicating presence of sufficient amount of variability in the germplasm under study. Such wide variation indicated the scope for improving the population for these characters.

The extent of variability in respect of the simple measures of variability like mean and range are presented in table 2 . The ranges of mean values revealed sufficient variation for all the traits under study. In the material under 
study, maximum range of variability (Table 2) was observed for average fruit weight $(230.00$ to $772.33 \mathrm{~g}$ ) followed by vine length (63.47 to $109.73 \mathrm{~cm})$ and days to last fruit harvest (97.00 to 119.67).

In general, phenotypic variances were higher than the corresponding genotypic variances for all the characters under study (Table 2). The phenotypic variance was highest for average fruit weight (10005.48) followed by vine length (226.70) and days to last fruit harvest (92.43). Similarly, the genotypic variance was also highest for average fruit weight (9039.79) followed by vine length (79.73) and days to appearance of first staminate flower (26.59). The phenotypic variance was lowest for pulp thickness $(0.05)$ followed by fruit yield (0.11) and number of fruits per vine (0.33). Similarly, the genotypic variance was lowest for pulp thickness and number of fruits per vine (0.02) followed by fruit yield (0.04) and rind thickness (0.14). High proportion of genetic variation (Table 2) implies that genetic variation plays an important role in the inheritance of yield attributes in muskmelon.

Genetic variability is essential in order to realize response to selection pressure. It has also been pointed out that the magnitude of genetic variability present in base population of any crop species is important in crop improvement and must be exploited by plant breeders for yield improvement. The estimates of PCV (Table 2) were highest for fruit yield $(28.30 \%)$ followed by fruit cavity length (28.20\%) and rind thickness (26.39\%), while lowest for days to appearance of first pistillate flower $(7.77 \%)$ followed by days to last fruit harvest $(8.97 \%)$ and days to first fruit harvest $(9.64 \%)$. The estimates of GCV (Table 2) were highest for fruit cavity length (26.66\%) followed by average fruit weight $(22.82 \%)$ and rind thickness $(22.14 \%)$, while lowest for days to last fruit harvest $(3.90 \%)$ followed by days to first fruit harvest $(3.99 \%)$ and days to appearance of first pistillate flower $(5.78 \%)$. Since genotypic coefficient of variation compares the relative amount of variability among attributes, it could, therefore, be deduced that fruit cavity length, average fruit weight and rind thickness had higher amount of exploitable genetic variability among the attributes. It also signifies that there is greater potential for favorable advance in selection in these attributes when compared to others.

The estimates of PCV (Table 2) were of high magnitude ( $>20 \%)$ for average fruit weight $(24.01 \%)$, number of fruits per vine $(20.66 \%)$, fruit cavity length $(28.20 \%)$, rind thickness (26.93\%), seed yield $(21.40 \%)$ and fruit yield (28.30\%), of moderate magnitude (10-20\%) for vine length $(18.53 \%)$, number of primary branches per vine (17.25\%), days to appearance of first staminate flower (12.30\%), node number of first pistillate flower (16.14\%), fruit length (19.38\%), fruit cavity width (16.30\%), pulp thickness $(14.46 \%)$ and total soluble solids $(10.81 \%)$ and of low magnitude $(<10.00 \%)$ for days to appearance of first pistillate flower $(7.77 \%)$, days to first fruit harvest $(9.04 \%)$, days to last fruit harvest $(8.97 \%)$ and fruit diameter $(9.80 \%)$. The estimates of GCV (Table 2) were of high magnitude $(>20 \%)$ for average fruit weight $(22.82 \%)$, fruit cavity length $(26.66 \%)$ and rind thickness $(22.14 \%)$, of moderate magnitude (10-20\%) for vine length $(10.99 \%)$, number of primary branches per vine $(13.07 \%)$, days to appearance of first staminate flower $(11.24 \%)$, node number of first pistillate flower (11.99\%), fruit length (17.75\%), fruit cavity width $(13.33 \%)$, total soluble solids $(10.05 \%)$, seed yield $(19.25 \%)$ and fruit yield (18.08\%) and of low magnitude $(<10 \%)$ for days to appearance of first pistillate flower $(5.78 \%)$, days to first fruit harvest (3.99\%), days to last fruit harvest $(3.90 \%)$, fruit diameter $(6.10 \%)$, number of 
fruits per vine $(5.40 \%)$ and pulp thickness $(8.60 \%)$. High degree of genetic variability for most of the characters in the present investigation offers a greater scope for effective selection.

In general, the magnitude of phenotypic coefficients of variation (PCV) was higher than the corresponding genotypic coefficients of variation (GCV) for all the seventeen characters under study (Table 2) indicating that these attributes had to some extent interacted with the environment. However, the differences between PCV and GCV were narrow indicating low environmental influence in the expression of these characters. However, the magnitudinal differences between the estimates of GCV and PCV were highest for number of fruits per vine (15.26) followed by fruit yield (10.22) and vine length (7.54). For other characters, the PCV and GCV values were close to one another, implying that genotype contributed more to the expression of these characters than environment, suggesting greater possibilities of improvement through selection.

Heritability is the only component which is transmitted to the next generation. The ratio of genetic variance to the total variance i.e., phenotypic variance is known as heritability. Heritability estimates gives a measure of transmission of characters from one generation to the next and the consistency in the performance of progeny in succeeding generations and depends mainly on the magnitude of heritable portion of variation. Heritability in broad sense is the ratio of genotypic variance to total variance in nonsegregating population (12).

Table.1 Analysis of variance for eighteen growth, earliness and Fruit yield attributes in muskmelon

\begin{tabular}{|c|c|c|c|}
\hline \multirow[b]{2}{*}{ Character } & \multicolumn{3}{|c|}{ Mean sum of squares } \\
\hline & $\begin{array}{l}\text { Replications } \\
\text { (2) }\end{array}$ & $\begin{array}{l}\text { Genotypes } \\
\text { (34) }\end{array}$ & $\begin{array}{l}\text { Error } \\
(68)\end{array}$ \\
\hline Vine length $(\mathrm{cm})$ & 586.76 & $386.17^{* * *}$ & 146.96 \\
\hline Number of primary branches per vine & 0.05 & $0.59^{* *}$ & 0.12 \\
\hline Days to appearance of first staminate flower & 11.9 & $85.03^{* *}$ & 5.24 \\
\hline Days to appearance of first pistillate flower & 7.88 & $42.92^{* *}$ & 9.08 \\
\hline Node number of first pistillate flower & 0.11 & $1.16^{* *}$ & 0.25 \\
\hline Days to first fruit harvest & 1.57 & $86.28^{*}$ & 50.02 \\
\hline Days to last fruit harvest & 571.37 & $127.34^{*}$ & 74.97 \\
\hline Fruit length $(\mathrm{cm})$ & 0.12 & $11.50^{* *}$ & 0.69 \\
\hline Fruit diameter $(\mathrm{cm})$ & 0.55 & $1.25^{* *}$ & 0.43 \\
\hline Average fruit weight $(\mathrm{g})$ & 381.46 & $28085.05^{* *}$ & 965.69 \\
\hline Number of fruits per vine & 1.37 & 0.38 & 0.31 \\
\hline Fruit cavity length $(\mathrm{cm})$ & 0.03 & $8.70^{* *}$ & 0.33 \\
\hline Fruit cavity width $(\mathrm{cm})$ & 0.01 & $1.34^{* *}$ & 0.19 \\
\hline Rind thickness (mm) & 0.06 & $0.48^{* *}$ & 0.06 \\
\hline Pulp thickness (cm) & 0.03 & $0.09^{* *}$ & 0.03 \\
\hline Total soluble solids ( ${ }^{\circ}$ Brix) & 0.31 & $1.43^{* *}$ & 0.07 \\
\hline Seed yield $\left(\mathrm{g}_{\text {fruit }}{ }^{-1}\right)$ & 0.04 & $2.06^{* *}$ & 0.15 \\
\hline Fruit yield $\left(\mathrm{kg}\right.$ plant $\left.^{-1}\right)$ & 0.18 & $0.19^{* *}$ & 0.06 \\
\hline
\end{tabular}


Table.2 Estimation of variability, heritability and genetic advance as percent of mean for 18 characters in 35 genotypes of muskmelon

\begin{tabular}{|c|c|c|c|c|c|}
\hline \multirow{2}{*}{ Character } & \multirow{2}{*}{$\begin{array}{l}\text { Mean } \pm \\
\text { S. Em }\end{array}$} & \multicolumn{2}{|l|}{ Range } & \multicolumn{2}{|l|}{ Variance } \\
\hline & & Minimum & Maximum & Phenotypic & Genotypic \\
\hline Vine length $(\mathrm{cm})$ & $81.24 \pm 7.00$ & 63.47 & 109.73 & 226.70 & 79.73 \\
\hline Number of primary branches per vine & $3.03 \pm 0.20$ & 2.27 & 4.20 & 0.27 & 0.16 \\
\hline $\begin{array}{l}\text { Days to appearance of first staminate } \\
\text { flower }\end{array}$ & $45.87 \pm 1.32$ & 35.07 & 55.20 & 31.84 & 26.59 \\
\hline Days to appearance of first pistillate flower & $58.08 \pm 1.74$ & 50.07 & 65.47 & 20.36 & 11.28 \\
\hline Node number of first pistillate flower & $4.60 \pm 0.29$ & 3.47 & 6.40 & 0.55 & 0.30 \\
\hline Days to first fruit harvest & $87.18 \pm 4.08$ & 78.67 & 96.67 & 62.11 & 12.09 \\
\hline Days to last fruit harvest & $107.21 \pm 5.00$ & 97.00 & 119.67 & 92.43 & 17.46 \\
\hline Fruit length $(\mathrm{cm})$ & $10.70 \pm 0.48$ & 7.92 & 16.33 & 4.30 & 3.61 \\
\hline Fruit diameter $(\mathrm{cm})$ & $8.56 \pm 0.38$ & 7.38 & 10.89 & 0.70 & 0.27 \\
\hline Average fruit weight (g) & $416.57 \pm 17.94$ & 230.00 & 772.33 & 10005.48 & 9039.79 \\
\hline Number of fruits per vine & $2.80 \pm 0.32$ & 2.13 & 3.47 & 0.33 & 0.02 \\
\hline Fruit cavity length (cm) & $6.26 \pm 0.33$ & 4.47 & 13.10 & 3.12 & 2.79 \\
\hline Fruit cavity width $(\mathrm{cm})$ & $4.65 \pm 0.25$ & 3.70 & 6.53 & 0.57 & 0.38 \\
\hline Rind thickness (mm) & $1.70 \pm 0.14$ & 1.17 & 2.67 & 0.20 & 0.14 \\
\hline Pulp thickness (cm) & $1.58 \pm 0.11$ & 0.97 & 1.99 & 0.05 & 0.02 \\
\hline Total soluble solids ( $\left.{ }^{\circ} \mathrm{Brix}\right)$ & $6.70 \pm 0.15$ & 6.00 & 9.10 & 0.53 & 0.45 \\
\hline Seed yield $\left(\mathrm{g}\right.$ fruit ${ }^{-1}$ ) & $4.14 \pm 0.22$ & 3.07 & 6.90 & 0.79 & 0.64 \\
\hline Fruit yield (kg plant $\left.{ }^{-1}\right)$ & $1.16 \pm 0.15$ & 0.57 & 1.70 & 0.11 & 0.04 \\
\hline
\end{tabular}

S. Em: standard error of mean

Table.2 (Continued)

\begin{tabular}{|c|c|c|c|c|c|}
\hline \multirow[t]{2}{*}{ Character } & \multicolumn{2}{|c|}{$\begin{array}{l}\text { Coefficient } \\
\text { variation }\end{array}$} & \multirow[t]{2}{*}{$\begin{array}{l}h^{2} \\
-(\%)\end{array}$} & \multirow{2}{*}{$\begin{array}{l}\text { Genetic } \\
\text { advance } \\
(\%)\end{array}$} & \multirow{2}{*}{$\begin{array}{l}\text { GA as } \\
\text { percent } \\
\text { of mean }\end{array}$} \\
\hline & $\mathrm{PCV}$ & GCV & & & \\
\hline Vine length (cm) & 18.53 & 10.99 & 35.17 & 13.98 & 17.21 \\
\hline Number of primary branches per vine & 17.25 & 13.07 & 57.45 & 0.79 & 26.16 \\
\hline Days to appearance of first staminate flower & 12.30 & 11.24 & 83.53 & 12.44 & 27.13 \\
\hline Days to appearance of first pistillate flower & 7.77 & 5.78 & 55.39 & 6.60 & 11.36 \\
\hline Node number of first pistillate flower & 16.14 & 11.99 & 55.12 & 1.08 & 23.49 \\
\hline Days to first fruit harvest & 9.04 & 3.99 & 19.46 & 4.05 & 4.64 \\
\hline Days to last fruit harvest & 8.97 & 3.90 & 18.89 & 4.79 & 4.47 \\
\hline Fruit length $(\mathrm{cm})$ & 19.38 & 17.75 & 83.92 & 4.59 & 42.93 \\
\hline Fruit diameter $(\mathrm{cm})$ & 9.80 & 6.10 & 38.73 & 0.86 & 10.02 \\
\hline Average fruit weight (g) & 24.01 & 22.82 & 90.35 & 238.59 & 57.27 \\
\hline Number of fruits per vine & 20.66 & 5.40 & 6.84 & 0.10 & 3.73 \\
\hline Fruit cavity length $(\mathrm{cm})$ & 28.20 & 26.66 & 89.41 & 4.17 & 66.56 \\
\hline Fruit cavity width (cm) & 16.30 & 13.33 & 66.93 & 1.34 & 28.79 \\
\hline Rind thickness (mm) & 26.39 & 22.14 & 70.39 & 0.83 & 49.04 \\
\hline Pulp thickness $(\mathrm{cm})$ & 14.46 & 8.60 & 35.40 & 0.21 & 13.51 \\
\hline Total soluble solids ( $\left.{ }^{\circ} \mathrm{Brix}\right)$ & 10.81 & 10.05 & 86.51 & 1.65 & 24.68 \\
\hline Seed yield $\left(\mathrm{g}\right.$ fruit $\left.^{-1}\right)$ & 21.40 & 19.25 & 80.90 & 1.89 & 45.71 \\
\hline Fruit yield $\left(\mathrm{kg} \mathrm{plant}^{-1}\right)$ & 28.30 & 18.08 & 40.82 & 0.35 & 30.50 \\
\hline
\end{tabular}

GCV: genotypic coefficient of variation; PCV: phenotypic coefficient of variation $h^{2}$ : heritability in broad sense; GA: genetic advance 
The estimates of heritability (Table 2) were of high magnitude $(>60 \%)$ for days to appearance of first staminate flower $(83.53 \%)$, fruit length $(83.92 \%)$, average fruit weight $(90.35 \%)$, fruit cavity length $(89.41 \%)$, fruit cavity width $(66.93 \%)$, rind thickness (70.39\%), total soluble solids $(86.51 \%)$ and seed yield (80.90\%), of moderate magnitude (30-60\%) for vine length $(35.17 \%)$, number of primary branches per vine $(57.45 \%)$, days to appearance of first pistillate flower $(55.39 \%)$, node number of first pistillate flower $(55.12 \%)$, fruit diameter $(38.73 \%)$, pulp thickness $(35.40 \%)$ and fruit yield $(40.82 \%)$ and of low magnitude $(<30 \%)$ for days to first fruit harvest $(19.46 \%)$, days to last fruit harvest $(18.89 \%)$ and number of fruits per vine $(6.94 \%)$.

High values of heritability for days to appearance of first staminate flower, fruit length, average fruit weight, fruit cavity length, fruit cavity width, rind thickness, total soluble solids, seed yield indicated that though the characters are least influenced by the environmental effects, the selection for the improvement of such characters may not be useful, because broad sense heritability is based on total genetic variance which includes both fixable (additive) and nonfixable (dominance and epistatic) variances. Such high heritability values in fruit and seed yield characters were also reported in muskmelon $(13,14-5)$.

The high heritability, therefore, implies that these yield attributes are controlled genetically, signifying high potential for improvement through selection. The moderate estimates of heritability for vine length, number of primary branches per vine, days to appearance of first pistillate flower, node number of first pistillate flower, fruit diameter, pulp thickness and fruit yield indicating that these characters are moderately influenced by environmental effects and genetic improvement through selection will be moderately difficult due to masking effects of the environment on the genotypic effects.

The estimates of heritability alone fail to indicate the response to selection. Therefore, heritability estimates appear to be more meaningful when accompanied by estimates of genetic advance and genetic advance as percentage over mean (11). The estimates of genetic advance as per cent of mean (Table 2) were of high magnitude $(>20 \%)$ for number of primary branches per vine $(26.16 \%)$, days to appearance of first staminate flower $(27.13 \%)$, node number of first pistillate flower $(23.49 \%)$, fruit length $(42.93 \%)$, average fruit weight $(57.27 \%)$, fruit cavity length $(66.56 \%)$, fruit cavity width $(28.79 \%)$, rind thickness $(49.04 \%)$, total soluble solids $(24.68 \%)$, seed yield $(45.71 \%)$ and fruit yield (30.50\%), of moderate magnitude $(10-20 \%)$ for vine length $(17.21 \%)$, days to appearance of first pistillate flower (11.36\%), fruit diameter (10.02\%) and pulp thickness $(13.51 \%)$ and of low magnitude $(<10 \%)$ for days to first fruit harvest $(4.64 \%)$, days to last fruit harvest $(4.47 \%)$ and number of fruits per vine $(3.73 \%)$.

High estimates of heritability ( $>60 \%$ ) coupled with high genetic advance as percent of mean (>20\%) for days to appearance of first staminate flower, fruit length, average fruit weight, fruit cavity length, fruit cavity width, rind thickness, total soluble solids and seed yield per fruit revealed that most likely the heritability is due to additive gene effects and selection may be effective. Such value of high heritability and high genetic advance may be attributed to the action of additive genes (16). The characters like days to appearance of first staminate flower, fruit length, average fruit weight, fruit cavity length, fruit cavity width, rind thickness, TSS and seed yield recorded high genetic advance as percent of mean coupled with high heritability estimates, 
indicating that these traits were under the strong influence of additive gene action, and hence simple selection based on phenotypic performance of these traits would be more effective. Similar kind of results in muskmelon was also reported by several researchers $(13,17-18)$. Low heritability and low genetic advance as percent of mean values were observed for the characters days to first fruit harvest, days to last fruit harvest and number of fruits per vine. This indicates the character is highly influenced by environmental effects and selection would be ineffective. Similar results were also reported by other researcher in muskmelon (17).

The analysis of variance revealed considerable amount of variation for all the characters studied except number of fruits per vine. Days to appearance of first staminate flower, fruit length, average fruit weight, fruit cavity length, fruit cavity width, rind thickness, total soluble solids and seed yield per fruit had high estimates of heritability coupled with high genetic advance as percent of mean. Hence, these characters need to be given more emphasis in selection as these are expected to be controlled by additive genes. The breeder should adopt suitable breeding methodology to utilize both additive and nonadditive gene effects simultaneously, since varietal and hybrid development will go a long way in the breeding programmes especially in case of muskmelon.

\section{Acknowledgements}

The authors are highly grateful to the National Bureau of Plant Genetic Resources Regional Station, Hyderabad for providing the germplasm of okra for the present study.

\section{References}

Ahmed, N.C.B. and Khaliq, I.M.M., 2007. The inheritance of yield and yield components of five wheat hybrid populations under drought conditions. Indonesian J Agric Sci, 8(2): 53-59.

Burton, G.W.,1952. Quantitative inheritance in grasses. Proc $6^{\text {th }}$ Int Grassland Congr 1; 277-283.

Hamdi, A., El-Chareib, A.A., Shafey, S.A. and Ibrahim, M.A.M.,2003. Genetic variability, heritability and expected genetic advance for earliness and seed yield from selections in lentil. Egypt $\mathbf{J}$ Agric Res, 81(1): 125-137, 2003.

Hanson, C.H., Robinson, H.R. and Comstock, R.S.,1956. Biometrical studies of yield in segregating population of Korean Lespedeza. Agron J, 48: 268-272.

Idahosa, D.O., Alika, J.E. and Omoregie, A.U.,2010. Genetic variability, heritability and expected genetic advance as indices for yield and yield components selection in cowpea (Vigna unguiculata (L) Walp). Academia Arena, 2 (5): 22-26.

Johnson, H.W., Robinson, H.F. and Comstock, R.S.,1955. Estimates of genetic and environmental variability in soybeans. Agron J, 47: 314-318.

Lush, J.L.,1940. Intersire correlations and regression of offspring on dams as a method of estimating heritability of characters. Proc Amer Soc Ani Breed, 33: 293-301.

Panse, V.G. and Sukhatme, P.V.,1985. Statistical methods for agricultural workers, Indian Council of Agricultural Research, New Delhi.

Panse, V.G.,1957. Genetics of quantitative characters in relation to plant breeding. Indian J Genet, 17: 318-329.

Rakhi, R. and Rajamony, L.,2005. Variability, heritability and genetic advance in landraces of culinary melon (Cucumis melo L.). J Trop Agric, 43(1/2): 79-82.

Shukla, S., Bhargava, A., Chattergee, A. and Singh, S.P., 2004. Estimates of genetic parameters to determine variability for 
foliage yield and its different quantitative and qualitative traits in vegetable amaranth (Amaranthus tricolor). J Genet \& Breed, 58: 169176.

Sivasubramanian, S. and Menon, M.,1973. Heterosis and inbreeding depression in rice. Madras Agric J, 60: 1139.

Songsri, P., Joglloy, S., Kesmala, T., Vorasoot, N., Akkasaeng, C.P.A. and Holbrook, C.,2008. Heritability of drought resistant traits and correlation of drought resistance and agronomic traits in peanut. Crop Sci, 48: 22452253.

Taha, M., El-Jack, A.E. and Omara, S.,2007. Estimation of genetic variability and broad sense heritability of some traits in melon (Cucumis melo. L.). Sudan J Agric Res, 8: 51-57.
Tazeen, M., Nadia, K. and Farzana, N.N.. 2009. Heritability, phenotypic correlation and path coefficient studies for some agronomic characters in synthetic elite lines of wheat. J Food Agric Environ, 7(3\&4): 278-282.

Tomar, R.S., Kulkarni, G.U., Kakade, O.K., Patel, A.D. and Acharya, R.R.,2008. Genetic divergence in muskmelon (Cucumis melo L.). Asian J Hort, 3(1): 103-105.

Torkadi, S.S., Musmade, A.M. and Mangave, K.K.,2007. Genetic variability studies in muskmelon (Cucumis melo L.). J Soils Crops, 17(2): 308-311.

Yadav, B., Tyagi, C.S. and Singh, D., 1998. Genetics of transgressive segregation for yield and yield components in wheat. An Appl Biol, 133: 227-235.

\section{How to cite this article:}

Praveen Kumar Reddy, B., Hameedunnisa Begum, N. Sunil and Thirupathi Reddy, M. 2017. Variance Component Analysis of Quantitative Traits in Muskmelon (Cucumis melo L.). Int.J.Curr.Microbiol.App.Sci. 6(6): 2277-2285. doi: https://doi.org/10.20546/ijcmas.2017.606.269 